VOL: 4, No. 1, JUNI 2017

ANTESEDEN LOYALITAS RELANGGAN DOMESTIK GARUDA INDONESIA DI KOTA AMBON

\title{
$\geqslant$
}

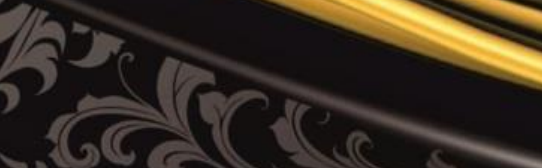

Saul Ronald Jacob Saleky

Jurusan Administrasi Bisnis, Politeknik Negeri Ambon

PENGARUH KECERDASAN EMOSIONAL DAN KECERDASAN SPIRITUAL TERHADAP KINERJA PERAWAT RUMAH SAKIT DAERAH LABUANG BAJI MAKASSAR Eka Suhartini \& Nur Anisa

Fakultas Ekonomi dan Bisnis Islam, Universitas Islam Negeri Alauddin Makassar FAKTOR YANG MEMPENGARUHI KEMAMPULABAAN PADA PERUSAHAAN PERIKANAN YANG TERCATAT DI BURSA EFEK INDONESIA (BEI

Suriyanti

Fakultas Ekonomi, Universitas Muslim Indonesia

PENGARUH KINERJA KEUANGAN TERHADAP HARGA SAHAM PADA SEKTOR INDUSTRI BARANG KONSUMSI YANG TERCATAT DI JAKARTA ISLAMIK INDEX (JII)

Rusdi Raprayogha \& Rusnawati

Fakultas Ekonomi dan Bisnis Islam, Universitas Islam Negeri Alauddin Makassar Djamila Abbas

Fakultas Akuntansi, Universitas Muhammadiyah Maluku Utara

PENGARUH BUDAYA ORGANISASI TERHADAP KINERJA PEGAWAI

PADA PT. PLN (PERSERO) WILAYAH SULSELRABAR

Rika Dwi Ayu Parmitasari, Wahidah Abdullah, \& Nirwana

Fakultas Ekonomi dan Bisnis Islam, Universitas Islam Negeri Alauddin Makassar

ANALISIS PERILAKU WISATAWAN DALAM MEMILIH OBYEK-OBYEK WISATA DI KABUPATEN GOWA

Asdi

Fakultas Ekonomi dan Bisnis, Universitas Muhammadiyah Makassar

PENGARUH KUALITAS LAYANAN DAN KEPUASAN PASIEN TERHADAP WORDS OF MOUTH PADA RUMAH SAKIT UMUM DAERAH DR. M. HAULUSSY AMBON Andrie Ch. Salhuteru

Jurusan Administrasi Bisnis, Politeknik Negeri Ambon INTENSITAS PENGGUNAAN ELECTRONIC BANKING OLEH NASABAH

PT. BANK CENTRAL ASIA CABANG UTAMA AMBON

Gilman Pary

Institut Agama Islam Negeri Ambon

FAKTOR-FAKTOR YANG MEMENGARUHI PERILAKU KONSUMEN DALAM PEMBELIAN PRODUK SOPHIE MARTIN DI KOTA MAKASSAR

Syaribulan

Universitas Indonesia Timur, Makassar 


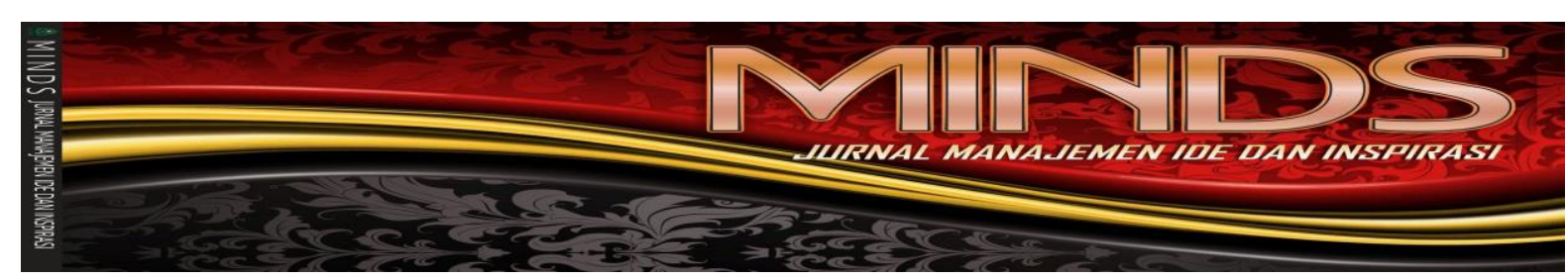

\section{KATA PENGANTAR}

\section{Assalamualaikum WR. WB.}

Puja dan puji syukur mari kita panjatkan ke hadirat Allah SWT, karena atas berkah dan karunia-Nya, maka Jurnal Manajemen dan Inspirasi (MINDS), Jurusan Manajemen, Fakultas Ekonomi dan Bisnis Islam, UIN Alauddin Makassar ini dapat diselesaikan. Salam dan shalawat kita haturkan kepada Nabi Muhammad SAW, sang pelita di tengah kejumudan dan kejahiliyahan, dan sumber informasi dan inspirasi yang terpercaya, beliaulah al-amiin. Terima kasih kami sampaikan kepada seluruh pihak yang terlibat dalam penyusunan jurnal Minds dari awal hingga akhir yang tidak dapat kami sebutkan satu persatu.

Adapun jurnal Minds merupakan sebuah kulminasi perwujudan kemamputulisan dari tenaga pendidik yang berada di intra Fakultas maupun luar universitas. Tulisan akademik yang diharapkan menjadi contoh nyata jawaban dari berbagai fenomena empiris yang relevan dari sisi keilmuan Manajemen. Edisi kali ini, yaitu Vol. 4, No.1, 2017, merupakan edisi terakhir yang fokus pada tulisan cetak, karena edisi berikut dari tulisan ini, yaitu untuk penerbitan periode desember akan fokus pada pengembangan Online Journal System dimana seluruh proses penerimaan, pengeditan, penelaahan kualitas tulisan akan diimigrasikan ke situs jurnal. Pengembangan ini diharapkan akan mendorong terciptanya proses yang lebih terukur baik dari penulis, mitra bestari, maupun penyunting, sehingga peningkatan kualitas publikasi ilmiah dapat diharapkan sebagai keluaran yang pasti.

Seiring dengan penerbitan jurnal ini, maka mewakili tim publikasi, saya menyampaikan rasa terima kasih yang sebesar-besarnya untuk seluruh penulis yang berpartisipasi dalam edisi kali ini, dan kepada para pembaca yang telah berkenan meluangkan waktunya untuk menelaah tulisan-tulisan yang termuat pada edisi kali ini.

Wassalamualaikum WR.WB.

Manajer Jurnal, 


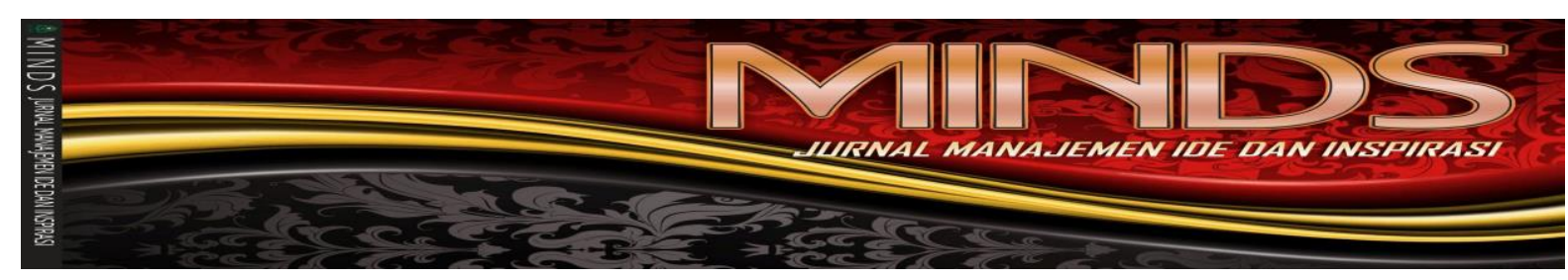

\section{DAFTAR ISI}

\section{ANTESEDEN LOYALITAS PELANGGAN DOMESTIK GARUDA INDONESIA}

DI KOTA AMBON.

Saul Ronald Jacob Saleky

Jurusan Administrasi Bisnis, Politeknik Negeri Ambon

PENGARUH KECERDASAN EMOSIONAL DAN KECERDSAN SPIRITUAL TERHADAP KINERJA PERAWAT RUMAH SAKIT DAERAH

LABUANG BAJI MAKASSAR

Eka Suhartini

Nur Anisa

Fakultas Ekonomi dan Bisnis Islam, Universitas Islam Negeri Alauddin Makassar

FAKTOR YANG MEMPENGARUHI KEMAMPULABAAN PADA PERUSAHAAN PERIKANAN YANG TERCATAT DI BURSA EFEK INDONESIA (BEI) .........

Suriyanti

Fakultas Ekonomi, Universitas Muslim Indonesia

PENGARUH KINERJA KEUANGAN TERHADAP HARGA SAHAM PADA

SEKTOR INDUSTRI BARANG KONSUMSI YANG TERCATAT

DI JAKARTA ISLAMIK INDEX (JII)

Rusdi Raprayogha

Rusnawati

Fakultas Ekonomi dan Bisnis Islam, Universitas Islam Negeri Alauddin Makassar

Djamila Abbas

Fakultas Akuntansi, Universitas Muhammadiyah Maluku Utara

PENGARUH BUDAYA ORGANISASI TERHADAP KINERJA PEGAWAI

PADA PT. PLN (PERSERO) WILAYAH SULSELRABAR.

Rika Dwi Ayu Parmitasari

Wahidah Abdullah

Nirwana

Fakultas Ekonomi dan Bisnis Islam, Universitas Islam Negeri Alauddin Makassar

ANALISIS PERILAKU WISATAWAN DALAM MEMILIH OBYEK-OBYEK

WISATA DI KABUPATEN GOWA

Asdi

Fakultas Ekonomi dan Bisnis, Universitas Muhammadiyah Makassar

PENGARUH KUALITAS LAYANAN DAN KEPUASAN PASIEN TERHADAP WORDS OF MOUTH PADA RUMAH SAKIT UMUM DAERAH

DR. M. HAULUSSY AMBON

Andrie Ch. Salhuteru

Jurusan Administrasi Bisnis, Politeknik Negeri Ambon

INTENSITAS PENGGUNAAN ELECTRONIC BANKING OLEH NASABAH PT. BANK CENTRAL ASIA CABANG UTAMA AMBON

Gilman Pary

Institut Agama Islam Negeri Ambon 
FAKTOR-FAKTOR YANG MEMENGARUHI PERILAKU KONSUMEN

\section{DALAM PEMBELIAN PRODUK SOPHIE MARTIN}

\section{KOTA MAKASSAR}

Syaribulan

Fakultas Ekonomi, Universitas Indonesia Timur, Makassar 


\title{
ANALISIS PERILAKU WISATAWAN DALAM MEMILIH
}

\section{OBYEK-OBYEK WISATA DI KABUPATEN GOWA}

Asdi *

\begin{abstract}
ABSTRAK
Keragaman obyek wisata di Kabupaten Gowa memerlukan suatu strategi pemasaran yang disesuaikan dengan karakteristik perilaku dan motivasi wisatawan . Penelitian ini bertujuan untuk mengetahui dan menganalisis adatidaknya perbedaan yang significant perilaku wisatawan dalam memilih obyek-obyek wisata di Kabupaten Gowa. Penelitian dilaksanakan di Kabupaten Gowa, dengan menjaring sebanyak 200 wisatawan sampel sebagai responden, pada enam lokasi obyek wisata. Untuk menentukan wisatawan sampel menggunakan teknik cluster sampling, quota sampling dan purposive sampling. Sedangkan teknik pengumpulan data menggunakan kuesioner, pengolahan dan analisis data menggunakan teknik analisis Kai-Kuadrat $\left(\mathrm{X}^{2}\right)$. Hasil olah dan analisis data menunjukkan bahwa ada perbedaan yang significant perilaku wisatawan dalam memilih obyek-obyek wisata di Kabupaten Gowa berdasarkan karakteristik wisatawan dengan indikator ; suku / asal daerah, kedudukan dan peran keluarga usia / tahap siklus hidup, dan indicator pengetahuan / proses belajar
\end{abstract}

Kata Kunci ; Karakteristik wisatawan, prilaku wisatawan memilih obyek wisata

\section{PENDAHULUAN}

\section{A. Latar Belakang}

Indonesia adalah negara yang memiliki aneka ragam sumber daya alam, aneka ragam budaya serta aneka ragam situs sejarah dan purbakala yang tersebar dari Sabang sampai Marauke dalam bingkai negara kesatuan Republik Indonesia yang ber-Bhinneka Tunggal Ika. Ke-bhinnekaan itu menjadikan Indonesia sebagai salah satu negara yang memiliki potensi dan prospek pariwisata yang dapat diandalkan untuk bersaing di kancah pasar pariwisata regional dan internasional.

Sulawesi Selatan memiliki potensi untuk memperoleh keuntungan dari sektor pariwisata karena posisinya yang sangat strategis sebagai pintu gerbang utama bagi wisatawan domestik dan mancanegara untuk memasuki daerah tujuan wisata di kawasan timur Indonesia. Sentra utama pembangunan kepariwisataan Sulawesi Selatan meliputi Makassar, Tana Toraja, dan Bulukumba.

\footnotetext{
* Prodi Manajemen FEB Unismuh Makassar, Jln. Sultan Alauddin No. 259 Gedung Iqra Lt.7-8 Makassar ( asdimuh@yahoo.co.id)
} 
Salah satu daerah yang termasuk wilayah pengembangan pariwisata (WPP) Makassar ialah Kabupaten Gowa yang memiliki obyek dan daya tarik wisata (ODTW) yang sangat beragam seperti obyek wisata alam, wisata sejarah, wisata budaya, wisata tirta dan wisata agro.

Keragaman obyek wisata itu memerlukan usaha pengembangan untuk diberdayakan sehingga mampu menarik wisatawan domestik maupun manca negara. Salah satu unsur manajemen pariwisata yang perlu mendapat prioritas adalah manajemen pemasaran. Untuk menetapkan strategi pemasaran yang tepat maka pasar sasaran (segmentasi pasar) sangat penting untuk diketahui. Oleh karena itu diperlukan informasi tentang karakteristik wisatawan dan pengaruhnya terhadap perilaku memilih obyek wisata.

\section{B. Rumusan Masalah}

1. Apakah terdapat perbedaan perilaku wisatawan dalam memilih obyek-obyek wisata di Kabupaten Gowa berdasarkan karakteristik suku / asal daerah?

2. Apakah terdapat perbedaan perilaku wisatawan dalam memilih obyek-obyek wisata di Kabupaten Gowa berdasarkan karakteristik kedudukan dan peran dalam keluarga?

3. Apakah terdapat perbedaan perilaku wisatawan dalam memilih obyek-obyek wisata di Kabupaten Gowa berdasarkan karakteristik usia / tahap siklus hidup?

4. Apakah terdapat perbedaan perilaku wisatawan dalam memilih obyek-obyek wisata di Kabupaten Gowa berdasarkan karakteristik pengetahuan dan proses belajar.?

\section{TINJAUAN PUSTAKA DAN HIPOTESIS}

\section{A. Tinjauan Pustaka}

\section{Pemasaran Pariwisata}

Pada prinsipnya pemasaran dapat diartikan sebagai cara bagaimana konsumen tertarik dengan barang dan jasa sesuai dengan yang diinginkan dalam waktu dan jumlah yang tepat, serta dengan harga yang layak.

Menurut Wahab (1997:34) pasar wisata adalah permintaan yang nyata atau yang masih potensial akan sesuatu produk wisata tertentu yang didasarkan pada sesuatu motivasi perjalanan.

Dalam bidang kepariwisataan, pemasaran juga dimaksudkan untuk merencanakan, menentukan harga, mempromosikan, dan mendistribusikan barang dan jasa kepada kelompok pembeli.

Dengan demikian pemasaran pariwisata adalah suatu proses manajemen dimana institusi kepariwisataan bersama dengan perusahaan industri pariwisata dapat menentukan permintaan jasa pariwisata baik aktual dan potensial, serta mengadakan komunikasi 
dengan mereka untuk menentukan dan mempengaruhi keinginan, kebutuhan, motivasi dan kepuasan pada lokasi obyek-obyek wisata.

\section{Pengertian Perilaku Konsumen ( Wisatawan )}

Dalam mengenal konsumen perlu memahami atau mengetahui prilaku konsumen sebagai perwujudan dari seluruh aktivitas jiwa manusia. Laudon dalam Mangkunegara (2002:3) mengemukakan bahwa perilaku konsumen dapat didefinisikan sebagai proses pengambilan keputusan dan aktivitas individu secara fisik yang dilibatkan dalam mengevaluasi, memperoleh, menggunakan, atau dapat menggunakan barang dan jasa

Dari pendapat diatas dapat disimpulkan bahwa perilaku konsumen adalah tindakan-tindakan yang dilakukan oleh individu kelompok atau organisasi dalam mendapatkan, menggunakan barang atau jasa yang dapat dipengaruhi oleh lingkungan.

\section{Karakteristik perilaku konsumen (Wisatawan).}

Kotler dan Armstrong (2001:196) mengatakan bahwa pembelian konsumen secara kuat dipengaruhi oleh karakteristik budaya, sosial, pribadi dan psikologis untuk jelasnya dapat dilihat pada gambar 1 .

a. Faktor Budaya

Setiap perilaku manusia akan menunjukkan tingkat kebudayaan yang tercermin dari cara hidup, kebiasaan dan tradisi dalam usaha memenuhi kebutuhan dan keinginannya.

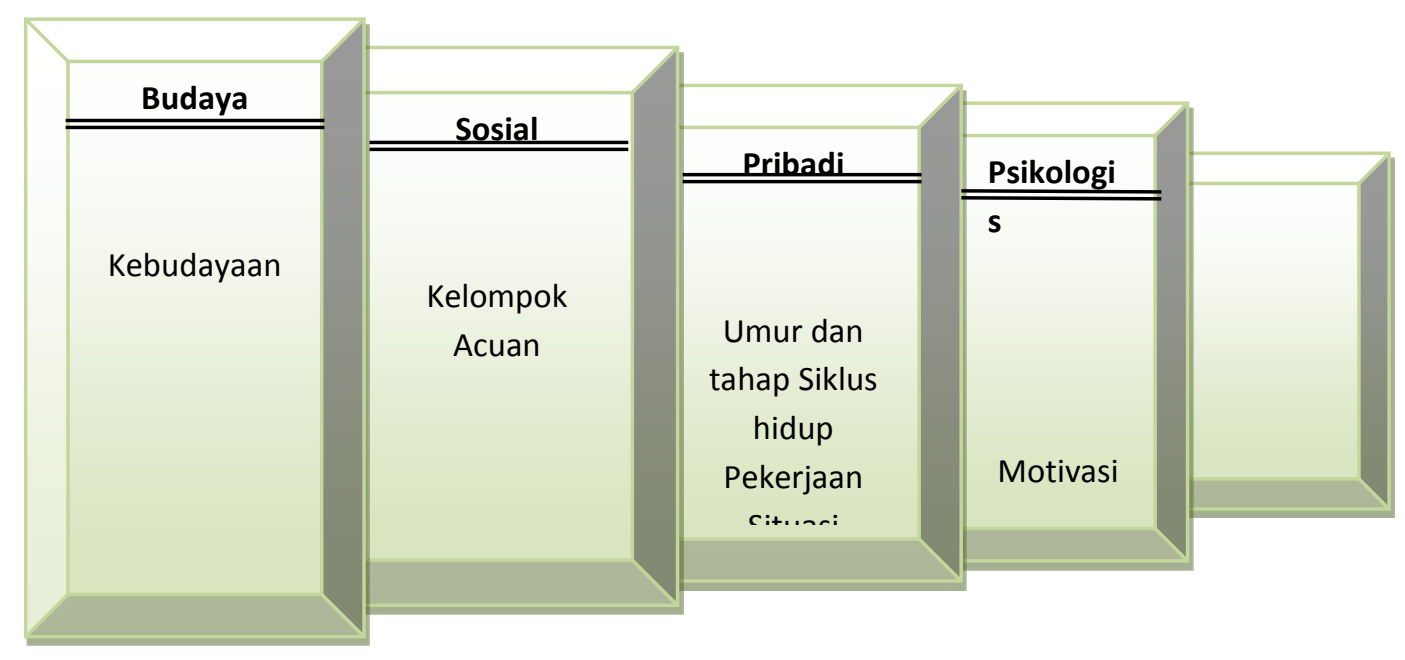

Gambar 1 : Faktor - faktor yang mempengaruhi perilaku konsumen

Sumber : Kotler dan Armstrong (2001:197) 
Stanton (1984 : 131) mendefinisikan kebudayaan adalah simbol dan fakta yang kompleks, yang diciptakan oleh manusia dalam masyarakat. Sedangkan Kotler (1997 : 153) mengemukakan bahwa budaya adalah penentu keinginan dan perilaku yang paling mendasar. Selanjutnya dinyatakan bahwa penggolongan subbudaya adalah terdiri atas bangsa, agama, kelompok ras, dan daerah geografis.

b. Faktor Budaya

Setiap perilaku manusia akan menunjukkan tingkat kebudayaan yang tercermin dari cara hidup, kebiasaan dan tradisi dalam usaha memenuhi kebutuhan dan keinginannya. Stanton (1984 : 131) mendefinisikan kebudayaan adalah simbol dan fakta yang kompleks, yang diciptakan oleh manusia dalam masyarakat. Sedangkan Kotler (1997 : 153) mengemukakan bahwa budaya adalah penentu keinginan dan perilaku yang paling mendasar. Selanjutnya dinyatakan bahwa penggolongan sub-budaya adalah terdiri atas bangsa, agama, kelompok ras, dan daerah geografis.

c. Faktor Keluarga

Keluarga dapat dikatakan sebagai suatu unit masyarakat yang terkecil yang perilakunya sangat mempengaruhi dan menentukan dalam pengambilan keputusan membeli barang dan jasa. Kotler (1997:158) mengatakan bahwa keluarga adalah organisasi pembelian konsumen yang paling penting dalam masyarakat. Keluarga terdiri dari keluarga orientasi yang terdiri dari orang tua dan saudara kandung seseorang, sedangkan keluarga prokreasi yaitu pasangan dan anak-anak seseorang. Peran yang dilakukan anggota keluarga dapat berubah-ubah, suatu saat sebagai pengambil keputusan dan pada saat yang lain berperan sebagai pelaku pembelian.

d. Faktor Usia Dan Tahap Siklus Hidup

Usia dan tahap siklus hidup yaitu suatu keadaan yang menggambarkan riwayat manusia sejak awal tahun kehidupannya sampai akhir hayatnya, atau dengan kata lain riwayat manusia sejak masa bayi sampai dengan masa tua. Menurut Kotler (1997 : 159) orang membeli jasa yang berbeda-beda sepanjang hidupnya, artinya tingkatan usia dan tahap siklus hidup seseorang akan berpengaruh terhadap selera seseorang terhadap konsumsi barang dan jasa.

e. Faktor Pengetahuan

Pengetahuan diartikan sebagai perubahan yang diakibatkan dari proses belajar Kotler (1997 : 165) mengemukakan bahwa pembelajaran meliputi perubahan dalam perilaku seseorang yang timbul dari pengalaman. Kebanyakan perilaku manusia dipelajari dimana ketika bertindak mereka belajar. Pengetahuan yang 
dihasilkan melalui proses belajar mempengaruhi dorongan, stimuli, petunjuk, tanggapan, dan pengetahuan. Proses pembelian yang dilakukan konsumen merupakan sebuah proses belajar.

\section{B. Hipotesis}

1. Ada perbedaan perilaku wisatawan dalam memilih obyek-obyek wisata di Kabupaten Gowa berdasarkan karakteristik suku/asal daerah .

2. Ada perbedaan perilaku wisatawan dalam memilih obyek-obyek wisata di Kabupaten Gowa berdasarkan karakteristik keluarga dalam memilih obyek-obyek wisata di Kabupaten Gowa berdasarkan karakteristik kedudukan dan peran dalam keluarga. .

3. Ada perbedaan perilaku wisatawan dalam memilih obyek-obyek wisata di Kabupaten Gowa berdasarkan karakteristik usia dan tahap siklus hidup

4. Ada perbedaan perilaku wisatawan dalam memilih obyek-obyek wisata di Kabupaten Gowa berdasarkan karakteristik pengetahuan dan proses belajar.

\section{METODE PENELITIAN}

\section{Lokasi dan Waktu Penelitian}

Penelitian ini dilaksanakan di Kabupaten Gowa Propinsi Sulawesi Selatan yang berlangsung pada bulan April s/d Juni 2016.

\section{Variabel Penelitian}

Penelitian ini terdiri dari dua variabel yakni variabel karakteristik wisatawan $(X)$ sebagai variabel berpengaruh yang terdiri dari 4 (empat) indikator yaitu :

a. Suku / asal daerah, terdiri atas 3 kategori atribut yaitu, Suku Makassar, Suku Bugis, dan Suku lainnya.

b. Keluarga terdiri atas 3 kategori atribut yaitu, suami, istri dan anak / anggota keluarga lainnya.

c. Usia dan tahap siklus hidup terdiri atas 3 kategori atribut yaitu dewasa, remaja dan anak-anak.

d. Pengetahuan / Proses belajar terdiri atas 3 atribut yaitu, pengalaman sebelumnya, dari mulut ke mulut, dan media informasi

Sedangkan variabel terpengaruh adalah perilaku konsumen dalam memilih obyek-obyek wisata di Kabupaten Gowa (Y), yang terdiri atas 3 (tiga) indikator yaitu :

a. Obyek wisata alam, terdiri atas 2 atribut obyek wisata alam yaitu Malino dan Bili-bili.

b. b. Obyek wisata sejarah, terdiri atas 2 atribut obyek wisata sejarah yaitu Makam Syekh Yusuf dan Makam Sultan Hasanuddin. 
c. Obyek wisata budaya, terdiri atas 2 atribut obyek wisata budaya yaitu Balla Lompoa dan Benteng Somba Opu

\section{Populasi dan Sampel}

Populasi ditentukan berdasarkan data pengunjung obyek-obyek wisata tahun 2015 sejumlah 105.584 wisatawan atau rata-rata sejumlah 8.798 wisatawan perbulan. (Gowa Dalam Angka tahun 2015), sedangkan besarnya sampel ditetapkan 2,5\% dari populasi yaitu 200 wisatawan sampel sebagai responden penelitian.

Teknik sampling menggunakan combined sampling yang penerapannya secara bertahap adalah sebagai berikut :

a. Cluster Sampling digunakan untuk menentukan obyek-obyek wisata yang akan dijadikan sasaran penelitian yaitu (1) obyek wisata alam ; Malino dan Bili-Bili, (2) obyek wisata sejarah ; Makam Syekh Yusuf dan Makam Sultan Hasanuddin, dan (3) obyek wisata Budaya ; $\quad$ Balla Lompoa, dan Benteng Somba Opu.

b. Quota sampling digunakan untuk menentukan besarnya sampel yang dianggap representatif pada masing-masing obyek wisata.

c. Purposive sampling digunakan untuk menentukan wisatawan sampel yang akan dijadikan responden.

Distribusi sampel dapat terlihat pada tabel 1 berikut :

Tabel 1

Distribusi Responden Menurut Obyek Wisata

\begin{tabular}{|c|c|c|c|c|c|c|}
\hline \multicolumn{6}{|c|}{ Frekwensi Responden Tiap Obyek Wisata } & \multirow[b]{3}{*}{ Jumlah } \\
\hline \multicolumn{2}{|c|}{ Wisata Alam } & \multicolumn{2}{|c|}{ Wisata Sejarah } & \multicolumn{2}{|c|}{ Wisata Budaya } & \\
\hline Malino & $\begin{array}{l}\text { Bili- } \\
\text { Bili }\end{array}$ & $\begin{array}{c}\text { Makam } \\
\text { Syekh } \\
\text { Yusuf }\end{array}$ & $\begin{array}{c}\text { Makam } \\
\text { Sultan } \\
\text { Hasanuddin }\end{array}$ & $\begin{array}{c}\text { Balla } \\
\text { Lompoa }\end{array}$ & $\begin{array}{c}\text { Benteng } \\
\text { Somba } \\
\text { Opu }\end{array}$ & \\
\hline 60 & 30 & 45 & 29 & 20 & 16 & 200 \\
\hline
\end{tabular}

Sumber : Hasil Penelitian, 2016

\section{Teknik Pengumpulan Data}

Tehnik yang digunakan dalam pengumpulan data yaitu kuesioner, wawancara dan observasi.

\section{Teknik Analisis Data}

Data yang terkumpul akan diolah dan dianalisis menggunakan tehnik analisis Kai-Kuadrat $\left(\mathrm{X}^{2}\right)$ dengan rumus :

$$
\begin{gathered}
\text { dimana }-f_{o}=\text { Frekwensi observasi } \\
-f t=\text { Frekwensi teoritis }
\end{gathered}
$$




$$
X^{2}=\sum \frac{\left(f_{0}-f_{t}\right)^{2}}{f_{t}}
$$

( Sudijono ; $1989: 353$ )

\section{HASIL PENELITIAN DAN PEMBAHASAN}

A. Suku / Asal Daerah Terhadap Perilaku Memilih Obyek Wisata

Tabel 2 berikut menggambarkan distribusi responden berdasarkan indikator suku / asal daerah dan prilakunya dalam menentukan pilihan obyek wisata di Kabupaten Gowa.

Tabel 2

Distribusi Responden Menurut Suku / Asal Daerah

\begin{tabular}{|l|c|c|c|c|}
\hline \multicolumn{1}{|c|}{$\begin{array}{c}\text { Suku / Asal } \\
\text { Daerah }\end{array}$} & Wisata Alam & $\begin{array}{c}\text { Wisata } \\
\text { Sejarah }\end{array}$ & $\begin{array}{c}\text { Wisata } \\
\text { Budaya }\end{array}$ & Jumlah \\
\cline { 2 - 5 } & 38 & 47 & 15 & 100 \\
\hline Suku Makassar & 35 & 15 & 10 & 60 \\
\hline Suku Bugis & 17 & 12 & 11 & 40 \\
\hline Suku Lainnya & 90 & 74 & 36 & 200 \\
\hline Jumlah & \multicolumn{4}{|c|}{} \\
\hline Hasil Analisis Data $: \mathbf{X}^{\mathbf{2}}$ hitung $=\mathbf{1 1 , 6 4 7} \mathbf{>}^{\mathbf{2}}$ Tabel $\mathbf{= 9 , 4 8 8}$ & \\
\hline
\end{tabular}

Sumber : Hasil Penelitian, 2016

Oleh karena nilai $\mathrm{X}^{2}$ hitung lebih besar dari $\mathrm{X}^{2}$ tabel $(11,647>$ 9,488), maka perbedaan data tersebut adalah signifikan. Berkaitan dengan hipotesis 1 (satu) yang menyatakan; ada perbedaan prilaku wisatawan dalam menentukan pilihan obyek - obyek wisata di Kabupaten Gowa berdasarkan indicator suku / asal daerah, "dapat diterima". Bahwa dengan adanya perbedaan tersebut menunjukkan bahwa faktor budaya / suku / asal daerah berpengaruh signifikan terhadap perilaku wisatawan dalam menentukan pilihan obyek-obyek wisata.

\section{B. Keluarga Terhadap Perilaku Memilih Obyek Wisata}

Tabel 3 berikut menggambarkan distribusi responden menurut kedudukan dan peran dalam keluarga, dan perilakunya dalam memilih obyek wisata di Kabupaten Gowa. 
Tabel 3

Distribusi Responden Menurut Peran Kedudukan dan Peran Dalam Keluarga

\begin{tabular}{|c|c|c|c|c|}
\hline \multirow{2}{*}{$\begin{array}{c}\text { Kedudukan Dalam } \\
\text { Keluarga }\end{array}$} & \multicolumn{3}{|c|}{ Pilihan Obyek Wisata } & \multirow[b]{2}{*}{ Jumlah } \\
\hline & $\begin{array}{l}\text { Wisata } \\
\text { Alam }\end{array}$ & $\begin{array}{l}\text { Wisata } \\
\text { Sejarah }\end{array}$ & $\begin{array}{l}\text { Wisata } \\
\text { Budaya }\end{array}$ & \\
\hline Suami & 19 & 28 & 13 & 60 \\
\hline Istri & 17 & 32 & 11 & 60 \\
\hline $\begin{array}{l}\text { Anak/Angt } \\
\text { Keluarga }\end{array}$ & 54 & 14 & 12 & 80 \\
\hline Jumlah\} $&{90} &{74} &{36} &{200} \\
$\hline
\end{tabular}

Sumber : Hasil olah data, 2016

Oleh karena nilai $\mathrm{X}^{2}$ hitung lebih besar dari $\mathrm{X}^{2}$ tabel $(29,989>$ 9,488), maka perbedaan data tersebut adalah signifikan. Berkaitan dengan hipotesis 2 (dua) yang menyatakan ; ada perbedaan prilaku wisatawan dalam menentukan pilihan obyek - obyek wisata di Kabupaten Gowa, berdasarkan indikator kedudukan dan peran dalam, keluarga "dapat diterima". Bahwa dengan adanya perbedaan tersebut menunjukkan bahwa faktor kedudukan dan peran dalam keluarga berpengaruh signifikan terhadap perilaku wisatawan dalam menentukan pilihan obyek-obyek wisata.

C. Usia / Tahap Siklus Hidup Terhadap Perilaku Memilih Obyek Wisata

Tabel 4 berikut menggambarkan distribusi responden berdasarkan indikator usia / tahap siklus hidup, dan perilakunya dalam menentukan pilihan obyek-obyek wisata di Kabupaten Gowa.

Tabel 4

Distribusi Responden Menurut Usia / Tahap Siklus Hidup

\begin{tabular}{|l|c|c|c|c|}
\hline \multirow{2}{*}{$\begin{array}{c}\text { Usia / Tahap } \\
\text { Siklus Hidup }\end{array}$} & \multicolumn{3}{|c|}{ Pilihan Obyek Wisata } & \multirow{2}{*}{ Jumlah } \\
\cline { 2 - 5 } & Wisata Alam & $\begin{array}{c}\text { Wisata } \\
\text { Sejarah }\end{array}$ & $\begin{array}{c}\text { Wisata } \\
\text { Budaya }\end{array}$ & \\
\hline Dewasa & 26 & 18 & 6 & 50 \\
\hline Remaja & 28 & 40 & 22 & 90 \\
\hline Anak-Anak & 36 & 16 & 8 & 60 \\
\hline Jumlah & 90 & 74 & 36 & 200 \\
\hline Hasil Analisis Data $: \mathbf{X}^{\mathbf{2}}$ hitung $=\mathbf{1 4 , 2 9 8}>\mathbf{X}^{\mathbf{2}}$ Tabel $\mathbf{= 9 , 4 8 8}$ & \\
\hline
\end{tabular}

Sumber : Hasil olah data, 2016

Oleh karena nilai $\mathrm{X}^{2}$ hitung lebih besar dari $\mathrm{X}^{2}$ tabel $(14,989>$ 9,488), maka perbedaan data tersebut adalah signifikan. Berkaitan dengan hipotesis 3 (tiga ) yang menyatakan; ada perbedaan prilaku wisatawan berdasarkan indicator usia / tahap siklus hidup dan 
perilakunya "dapat diterima". Dengan adanya perbedaan tersebut menunjukkan bahwa factor usia / tahap siklus hidup berpengaruh signifikan terhadap perilaku wisatawan dalam menentukan pilihan obyek-obyek wisata.

\section{Pengetahuan Terhadap Perilaku Memilih Obyek Wisata}

Tabel 5 berikut menggambarkan distribusi responden menurut indicator pengetahuan / proses belajar dan perilakunya dalam menentukan pilihan obyek-obyek wisata.

\section{Tabel 5}

Distribusi Responden Pengetahuan / Proses Belajar

\begin{tabular}{|l|c|c|c|c|}
\hline \multirow{2}{*}{$\begin{array}{l}\text { Pengetahuan / } \\
\text { Proses Belajar }\end{array}$} & Wisata Alam & $\begin{array}{c}\text { Wisata } \\
\text { Sejarah }\end{array}$ & $\begin{array}{c}\text { Wisata } \\
\text { Budaya }\end{array}$ & \multirow{2}{*}{ Jumlah } \\
\cline { 2 - 5 } & $\begin{array}{l}\text { Pengalaman } \\
\text { Sebelumnya }\end{array}$ & 15 & 7 & 60 \\
\hline $\begin{array}{l}\text { Dari Mulut ke } \\
\text { Mulut }\end{array}$ & 32 & 29 & 14 & 75 \\
\hline Media Informasi & 20 & 30 & 15 & 65 \\
\hline Jumlah & 90 & 74 & 36 & 200 \\
\hline Hasil Analisis Data : $\mathbf{X}^{\mathbf{2}}$ hitung $=\mathbf{1 3 , 6 4 7}>\mathbf{X}^{\mathbf{2}}$ Tabel $\mathbf{= 9 , 4 8 8}$ \\
\hline
\end{tabular}

Sumber : Hasil olah data, 2016

Oleh karena nilai $\mathrm{X}^{2}$ hitung lebih besar dari $\mathrm{X}^{2}$ tabel $(13,647>$ 9,488), maka perbedaan data tersebut signifikan. Berkaitan dengan hipotesis 4 (empat) yang menyatakan ; ada perbedaan prilaku wisatawan dalam memilih obyek wisata di Kabupaten Gowa,berdasarkan indikator pengetahuan / proses belajar, "dapat diterima". Dengan adanya perbedaan tersebut menunjukkan bahwa faktor pengetahuan / proses belajar berpengaruh terhadap perilaku wisatawan dalam menentukan pilihan obyek-obyek wisata.

\section{E. Pembahasan}

Betrdasarkan hasil olah dan analisis data tentang karakteristik perilaku wisatawan dalam memilih obyek-obyek wisata di Kabupaten Gowa berdasarkan indicator-indikator sebagaimana terdeskripsikan masingmasing pada table 2,3,4, dan tabel 5 diatas, maka hasil olahan dan analisis datanya secara ringkas dapat dirangkum pada table 6 berikut : 
Tabel 6. Rangkuman Hasil Analisis data Variabel Karakteristik Wisatawan Dalam memilih Obyek-obyek Wisata Di Kabupaten Gowa

\begin{tabular}{|c|c|c|c|c|}
\hline No. & $\begin{array}{c}\text { Indikator Variabel } \\
\text { Karakteristik Wisatawan }\end{array}$ & $\begin{array}{c}\text { Nilai X } \\
\text { Hitung }\end{array}$ & $\begin{array}{c}\text { Nilai X2 } \\
\text { Tabel }\end{array}$ & $\begin{array}{c}\text { Keterangan } \\
\text { Signifikan }\end{array}$ \\
\hline 1. & Suku / asal daerah & 11,647 & 9,488 & Signifikan \\
\hline 2. & $\begin{array}{c}\text { Kedudukan dan peran } \\
\text { dalam Keluarga }\end{array}$ & 29,298 & 9,488 & Signifikan \\
\hline 3. & $\begin{array}{c}\text { Usia / Tahap Siklus } \\
\text { Hidup }\end{array}$ & 14,989 & 9,488 & Signifikan \\
\hline 4. & $\begin{array}{c}\text { Pengetahuan / Proses } \\
\text { Belajar }\end{array}$ & 13,647 & 9,488 & Signifikan \\
\hline
\end{tabular}

Memperhatikan hasil analisis data pada table tersebut di atas menunjukkan bahwa terdapat perbedaan yang signifikan perilaku wisatawan dalam memilih obyek-obyek wisata di Kabupaten Gowa berdasarkan karakteristik masing-masing wisatawan yang terdiri dari indicator ; suku / asal daerah, kedudukan dan peran dalam keluarga, usia / tahap siklus hidup, dan indicator pengetahuan / proses belajar.

Bahwa dengan adanya perbedaan yang signifikan tersebut maka dapat disimpulkan bahwa penentuan keputusan wisatawan dalam memilih obyek-obyek wisata secara simultan dipengaruhi oleh factor perbedaan karakteristik wisatawan yang terdiri dari ; suku/asal daerah, kedudukan dan peran dalam keluarga, usia/ tahap siklus hidup, dan pengetahuan / proses belajar. Adapun konsep dan teori yang mendukung kesimpulan tersebut dikemukakan oleh Kotler dan Armstrong (2001:196) yang menyatakan bahwa pembelian konsumen secara kuat dipengaruhi oleh karakteristik budaya, sosial, pribadi dan psikologis.

\section{SIMPULAN DAN SARAN}

\section{A. Simpulan}

1. Secara parsial variabel karakteristik wisatawan yang terdiri dari indikator ; suku/asal daerah, keluarga, usia/tahap siklus hidup, dan pengetahuan berpengaruh signifikan terhadap variabel perilaku wisatawan dalam menentukan pilihan obyek-obyek wisata di Kabupaten Gowa yang terdiri dari obyek wisata alam, obyek wisata sejarah dan obyek wisata budaya

2. Diantara keempat indicator pada variabel karakteristik wisatawan maka indikator keluarga berpengaruh dominan terhadap variabel perilaku wisatawan dalam memilih obyek-obyek wisata karena memiliki nilai $\mathrm{X}^{2}$ hitung yang tertinggi $(29,989)$ dibandingkan faktor - faktor lainnya. 


\section{B. Saran}

1. Program promosi pariwisata di Kabupaten Gowa hendaknya menerapkan strategi segmentasi pasar dengan memperhatikan karakteristik wisatawan seperti faktor budaya, faktor keluarga, faktor usia / tahap siklus hidup dan faktor pengetahuan yang disesuaikan dengan jenis obyek wisata yang diunggulkan untuk dipasarkan.

2. Penelitian ini hanya meneliti empat variabel yang dapat berpengaruh terhadap perilaku wisatawan, olehnya itu diharapkan agar peneliti lain yang berminat dapat mengkaji variabel seperti kelas sosial, kelompok acuan, pekerjaan, gaya hidup kepribadian, motivasi dan sebagainya.

\section{DAFTAR PUSTAKA}

J. Stanton William Y Lamarton ; 1985, Pemasaran, Erlangga, Jakarta Kother, Philip ; 1995, Manajemen Pemasaran, Prenhalindo, Jakarta Kotler, Philip \& Armstrong; 2001, Prinsip-Prinsip Pemasaran, Erlangga, Jakarta Kusmayadi, dan Sugiarto, Endar, 2000, Metodologi Penelitian Dalam Bidang Kepariwisataan, PT. Gramedia Pustaka Utama, Jakarta.

Mangkunegara, Anwar Prabu; 2002, Prilaku Konsumen, PT. Refika Aditama, Bandung

Marpaung, Happy, 2002, Pengetahuan Kepariwisataan, Alfabeta, Bandung. Muljadi, 2009, Kepariwisataan dan Perjalanan, Raja Grafindo Persada, Jakarta.

Soewantoro, Gamal ; 2001, Dasar-Dasar Pariwisata, Andi, Yogyakarta Sudijono, Anas ; 1989, Pengantar Statistik Pendidikan, Rajawali Pers, Jakarta Pitana, I Gede, dan Surya Diarta, I Ketut, 2009, Pengantar Ilmu Pariwisata, Andi, Yogyakarta.

Wahab, Salah; 1997, Pemasaran Pariwisata, PT. Praduya Paramita, Jakarta 